\title{
Investigating Determining Factors of the Financial Structure in a Context of an Underdeveloped Financial Market: An Example of Cameroonian SMEs
}

\author{
Aboubakar Mfopain ${ }^{1}$ \\ ${ }^{1}$ Faculty of Economics and Management, University of Ngaoundéré, Cameroon \\ Correspondence: Aboubakar Mfopain, Faculty of Economics and Management, University of Ngaoundéré, \\ Cameroon. E-mail: abmfopain@yahoo.fr
}

Received: August 25, 2014

Accepted: February 12, 2015

Online Published: March 27, 2015

doi:10.5539/ijbm.v10n4p232

URL: http://dx.doi.org/10.5539/ijbm.v10n4p232

\begin{abstract}
This study examines the determinants of the financial structure in a context where the financial market is still embryonic. From a sample of 62 enterprises, the research carried out permit to highlight the fact that the financial structure in the small and medium size enterprises is more influenced by certain profile characteristics than others. Thus, the structure of shareholding, the size stated in terms of the number of employees and the nature of property, introduce a high discrimination between non rated enterprises and this with regards to the importance of their owned capital. Also, the importance of negative working capital and the speed of economic access explain the differences between group of enterprises from the point of view of financing equilibrium, as well as the distribution rate of the dividends and profitability which are reputed in explaining significantly the differences in the indebtedness rate as far as the SME of our sample are concerned.
\end{abstract}

Keywords: financial structure, owned capital, profile, working capital, debt rate

\section{Introduction}

SMEs (Small and medium sized enterprises) due to many constraints and variables including those relating to their specificities towards the theory of modern finance, and the supervisory system are unable to obtain funds that are able to meet with their expectations (Yassine, 2013). Thus, the question on the financing of the company understood as defining the proportion of debt and equity or preference for internal or external financing has always implied disputes and reflections (Desbrières \& Dumontier, 1989, Harris \& Raviv, 1991). In addition, the findings are not always approved by a majority of theorists and practitioners of modern finance (Colot \& Croquet, 2007; Trahan \& Gitman, 1995). These questions do not really have an explanatory theoretical framework that can be used here as an appropriate framework for decisions for firms (Ndoume, 2003).

If one recognizes that more than $80 \%$ of SMEs die during the first five years of their existence, and that one of the crucial reasons for this failure is probably still the problem of financing, it must also be recognized that a key factor to the success of SME is and remains the undisputed choice of a suitable financial structure, especially with Hirigoyen and Jobar (1989), it is no longer possible to make a dichotomy between financing decisions and investment choices. Reasons for the insufficiency in financing SME are not only numerous but they depend on the responsibility of enterprises and that of banks. In fact, as far as bankers are concerned, SME are too risky because of the insufficiency in owned capital and the important cost of their follow up (Fotsa, 2014). These factors do not plead in the favor of these enterprises for which banks do not always find any interest in financing them due to their lack of knowledge and experience on the work of proximity with the latter (Le Filleur, 2009). In this light, the transactional behavior of banks hampers the development of SME given that behaviors of banks are characterized by the imposition of guarantees of a tangible nature and the non renegotiation as the condition of loan, the increment of the interest rate of short termed loans and the preference for immediately profitable investments (Tioumagneng, 2012; Yassine, 2013). This is in opposition to the neoclassical financing theory of rationalization which based the decision of granting of loans by banks on the internal conditions of credit worthiness and profitability (Stiglitz \& Weis, 1981). Consequently, the financial structure is partly determined by internal forces facing the monopoly of banks in terms of loans offers, internal factors and especially those related to the negotiating power of leaders permit them to control their politics of indebtedness themselves and to 
undergo the opportunism of banks (Cordier \& Sicsic, 1999).

In Cameroon, SME are a form of the most representative organization in the economic sphere, and the diversity of financial structures observed gives rise to the question on the rationality of the financing behavior of these firms. While the financial theory has gradually identified a whole series of internal determinants of the financing behavior of the enterprise, it also raised the importance or relevance of contextual and institutional differences. Moreover, these studies have focused, in most cases, on industrialized countries and in environments where there is a relatively efficient financial market and where financial systems are changing. Studies in this field in Africa are still non-existent or very few. It is inexorably that in this context the problem of maximizing of the value of the firm through a financing structure remains fully justified. In this sense, the search of explanatory factors of an optimum and proportional distribution between owned equity and borrowed fund still remains topical. However, several neo-classical and contemporary theories are much more built by highlighting factors that explain the financial structure and are still causing too much controversies and show inconsistencies in their adaptation to the case of SME. In fact, the classical approach of investment and financing which inspires the choice of a financing structure is developed in an accountant framework and lack a solid theoretical foundation. The theory of Miller and Modigliani since 1958 on its part is based on the concept of perfect market and depends on simplistic hypotheses. The first is difficult to be realized in a context of informational asymmetry and the second leads to a restriction of the reality of the maximization of the firm and of the double relation between the decision of financing and investment.

Moreover, if the empirical results generally observed most often seem to confirm the theoretical assumptions, only a few of them are orientated towards the test of an identified model (Rainelli-Le-Montagner, 1998). Therefore, the meaning and the sign of the impact of the determinants on the choice of a financial structure are not subject to a consensus.

From these multiple findings, one is entitled to ask himself a question like: what are the elements that at certain points, influence the choice of Cameroon SME between equity financing and/or borrowed funds, and especially in a context marked by the absence of a worthy financial market?

With regard to their specific characteristics, several questions are important for facilitating this research namely:

Are the factors affecting the choice of financial structure within Cameroonian companies related to their profile characteristics, operation or to certain levels of achievement in their performances? Which of these factors can help to explain differences in financial structure observed between these SME?

The purpose of this article is therefore based on the description of the interactions between the financial structure of a SME and elements helping to define it, or better, the analysis focused on the characteristic features of financing Cameroon SME.

\section{Theoretical and Methodological Framework}

This research is based on the deductive logic justified by the validation of a set of hypotheses. It is grounded on the verification and validation of a theoretical assumptions carefully constructed, based on the results of existing research in the field and in other contexts.

In general, the literature review suggests that the problem of choosing a financial structure is basically summarized in the definition of leverage or ratio between debt and equity in connection with the profile characteristics, operating business and profitability performance and growth of these latter. The assumptions used here are those which characterize the influence of these variables on the level of equity or debt of the companies concerned.

\subsection{Basic Assumptions and Hypotheses}

Different studies show that companies face difficulties and financial needs of nature and/or different intensities, depending on whether they are at one stage or another of their evolution. Studies of the National Fund for government contracts in France (1997) also show that the major problem of the survival of SME is related to financing, which is often associated with their age. From the empirical studies conducted by different authors, it is clear that there is a negative and statistically significant effect between firm's age and its level of financing debt (Bourdieu \& Colin Sédillot, 1993; Johnson, 1997).

The company's age therefore appears as a factor likely to discriminate between Cameroonian SME, especially from the point of view of the proportion of equity in the global financial structure of these companies. In Cameroon as well as everywhere elsewhere, enterprises are financially constrained during the first five years covering their starting period. As time goes by, the profits become progressively important to supply their 
self-financing and reserves and modify consequently the proportion of owned equity in connection with borrowed funds in their financing structure.

Moreover, the influence of the size of the firm on its debt level refers to extensive research. Empirical studies agree on the existence of a size effect on the financial structure. Many authors lead to a positive relationship between size (measured by turnover, the number of employees or total assets) and the use of leverage (Shuetrim et al., 1993; Bédué 1997; Gaud \& Jani, 2002; Rajan \& Zingales, 1995; Croquet et al., 2013) while others argue that the dosage between debt and equity depends to a large extent on the size (Dubois, 1985) or that this latter is negatively connected to the debt of very large companies (Malécot, 1982; Carpentier \& Suret, 2000; Bourdieu \& Sédillot, 1993; Johnson, 1997). In the same vein, Biais et al. (1995) show that the relationship between bank loans and firm size evolves according to an inverted V shape, reflecting the fact that smaller and larger firms borrow less from banks than average firms. Following the previous authors, Scott (1976) argues that the mixing of debt and equity depends largely on size. However, Remmers et al. (1974); Fontaine and Njiokou (1996) conclude rather to a lack of a relationship between size measured by the turnover and use of leverage. Studies conducted in France reveal that, whatever the criterion and stratum of size taken, firms suffer from a lack of capital. Redis (2002) shows that large firms are more diversified than small ones and can assume greater financial risks and therefore are more leveraged than the first ones.

The influence of the industry on the financial structure has no clear theoretical justification (Bias et al., 1995). However, the industry is a first approximation of the risk of business activity (Dubois, 1985). Similarly, the importance of financing needs depends on the degree of capital intensity of the industry. Furthermore, the technical and economic features of an area are likely to influence the financial structure of firms that abounds. We can thus say that the proportion of equity held by the Cameroonian SME vary according to their industry.

In connection with the risk of default and the presence of information asymmetries, the variables measuring the importance of safeguards in companies' balance sheets (fixed assets, payroll expenses, tangible assets) are positively related to debt ratios (Dubois, 1985; Bourdieu \& Colin Sédillot, 1993; Bédué, 1997; De Jong \& Van Dijk, 1998). Since Cameroonian SME as others elsewhere face difficulties obtaining loans for lack of guarantees and collaterals, their access to financing is therefore limited because of the size effect which leads to some unfavorable prejudices. The diagram proposed by the supporters of the hierarchical theory of financing according to which the SME give priority first to self-financing then borrowing, can be best adapted to their mode of financing. The size is therefore presented as an indicator of financial constraints according to (Fazzari et al., 1988). Financial combination in a financing structure depends therefore on the size of the enterprise concerned.

In the last group of factors are the structure and nature of the property that rely this time on the theoretical framework of the agency, its influence on the financial structure based on the work of Jensen and Meckling (1976). Indeed, as and when ownership is dispersed, control costs, customs clearance and residual costs are rising faster than the cost of debts. It then results that, beyond a certain threshold of dispersion of capital, the company will use more lenders than new shareholders. In addition, Harris and Raviv (1988) and Stulz (1998) showed that debt is an anti-takeover measure because it affects the distribution of voting power between managers and passive investors. We can also learn from the literature review that the intensity of control has an influence on the allocation between equity and debt (Pioncelot, 1999; Njiokou \& Fontaine, 1996). Indeed, firms that are controlled by a family, a group without affinity or by financial institutions, do not have the same potentials concerning the use of debt (Charreaux, 1991; Bourdieu \& Colin Sédillot, 1993; Allouche \& Amann 1995; Sassenou, 1996). So, can we say therefore in the case of Cameroon, that the importance of equities of a SME depends on the nature of its property on the one hand, the number of shareholders and the intensity of the control on the other hand?

Finally, the level of equities of Cameroonian SME depends on its profile characteristics (H1). Four Sub-hypothesis arises from this main hypothesis:

$\mathrm{H}_{1-1}$ The age or period of life influences the level of own funds in Cameroon SME.

$\mathrm{H}_{1-2}$ The size of the Cameroonian SME influences its level of equities.

$\mathrm{H}_{1-3}$ The proportion of owned capital held by the SME varies with its activity sector.

$\mathrm{H}_{1-4}$ The importance of equities of a SME varies, depending on the nature of the capital property.

Moreover, the financial problems of the company (including reduced size) must be reconciled with the characteristics of its operations. These latter have an influence on the financing needs and direct or indirect effect on the financial structure. Indeed, the rotation of the economic assets depending on whether it is fast or slow has 
an impact on the capital assets in the company and on the profitability (Chakib El Fakhori, 1985). A period of high stock rotation highlights a need for additional funding that can generate discomfort and influence the financial equilibrium if an equity contribution is not made, or if desired, when there is a disproportionate use of a short-term debt. Thus, the working capital of the company varies with the speed of economic assets and/or its speed of rotation of stocks.

In addition, the duration of the intercompany trade credit can lead to significant needs of capital for SME. It then has an impact on self-financing and may explain its financial fragility. Thus, Hirigoyen (1982) highlighting the impact of intercompany credit on the cash flow capacity notes the existence of two groups of firms with different financing problems depending on the control or not of the intercompany credit: The working capital of the Cameroon SME depends on the duration of credit suppliers and customers. Moreover, the importance of the need for working capital can cause a situation of lack of equities on the one hand, due to the weakening of the cash flow that results, and on the other hand, because the coverage of this negative working capital, will prove all things being equal and therefore insufficient. The importance of this negative working capital can modify the financial structure and thus, the risk that the company faces (Malécot, 1982). It can therefore be assumed that the higher the negative working capital of a company, the more important is its working capital.

In view of the foregoing, we can retain the fundamental hypothesis that:

The importance of the working capital of the Cameroonian SME depends on its operating characteristics (H2). From this main hypothesis arises five sub-hypothesis:

$\mathrm{H}_{2-1}$ The level of working capital of Cameroonian SME depends on the speed of its economic assets.

$\mathrm{H}_{2-2}$ The level of working capital of Cameroonian SME vary with the speed of its rotation of stocks.

$\mathrm{H}_{2-3}$ Working capital of Cameroonian SME depends on the duration of the supplier credit.

$\mathrm{H}_{2-4}$ Working capital of Cameroonian SME depends on the duration of a customer credit.

$\mathrm{H}_{2-5}$ The more need for negative working capital by a SME, the greater its working capital is increased.

However, it should be noted that many companies' decisions are made based on the positions of these latter towards the profitability and growth of their firms. Thus the decisions of the tax policy focused on the structure adopted by the company according to its profitability target, risk and growth.

Referring to the arguments of the theory of hierarchical financing, the most profitable companies should be characterized, all things being equal to a small debt level (Meyers, 1977). Conversely, according to the proponents of the theory of signal, banks will increase the borrowing capacity of the most profitable firms using profitability increased in the risk assessment of companies (Ross, 1977).

At the same time, the financial return being the product of economic profitability by its level of indebtedness, it therefore appears that the weight of this debt can magnify this profitability which leverage is the resultant (Dubois, 1985; Shuetrim et al., 1993; Nekhili, 1994; Sassenou \& Mulkay, 1995; Bédué, 1997; Suret \& Carpentier, 1999; Myers \& Majluf, 1984) also postulates that the distribution policy is a signal of performance and acts in the same direction as profitability. Studies carried out in Cameroon by Mai Django and Tsapi (2013) on the determinants of the distribution of dividends and in a context of the embryonic financing market reveals that the shareholding concentration, the investment level and the total debt negatively affect the frequency of dividend distribution. On the other hand, profitability plays a key role on dividend distribution. Whatever the level of profitability of a firm, the debt is negatively correlated with the risk of activity (Leyland \& Pyle, 1977).

Logically, the higher the cash flow of a company, the lower the indebtedness dependency of the latter to use debt to finance itself (Bourdieu \& Colin Sédillot, 1993; Nekhili, 1994; Mulkay \& Sassenou, 1995). This negative influence is also the case for profitability (Biasand et al., 1995; Rajan \& Zingales, 1995; Kremp \& Stöss, 2001; Gaud \& Jani, 2002).

The rate of a firm growth as well as the investment opportunities impact the debt ratio of the firm because auto financing alone cannot ensure the financing of new investments. Therefore, Meyers (1977) showed that the tendency of shareholders' managers to avoid undertaking investment projects that only benefit creditors is even stronger than the growth opportunities are important. Similar results are obtained for firms experiencing significant growth (measured by the change in total assets, turnover or the investment rate) causing a strong need for financing (Carpentier \& Suret, 2000; Shuetrim et al., 1993; Stöss \& Kremp, 2001) although other authors note rather a negative influence on the growth rate of debt or not at all like Toy et al. (1974) and Rajan and Zingales (1995) or Gaud and Jani (2002) for growth opportunities or investments. We can deduce on the one hand, that the more the growth rate is high, the greater the debt rate and secondly, the level of investment 
opportunities negatively affects the debt of Cameroonian SMEs.

The risk on activity can damage at the same time the profitability and growth of the company and tends to limit the borrowing because for a given level of debt, the risk of failure increases with the flow from the exploitation. This level of risk is moderated by the asset composition (Jensen \& Meckling, 1976) and by the degree of asset specificity (Williamson, 1988) that also influences the firm leverage level. It also establishes the positive influence of tangibility of assets on the use of leverage of the firm (Shuetrim et al., 1993; Biais et al., 1995; Rajan \& Zingales, 1995; Johnson, 1997; Gaud \& Jani, 2002).

We can therefore expect that debt is negatively correlated with the risk of activity. This allows to state that:

The financial debt rate of Cameroonian SMEs is influenced by its performance history (H3). Five sub-hypothesis comes out from this main hypothesis:

$\mathrm{H}_{3-1}$ The indebtedness level of Cameroonian SME is influenced by their rate of profitability.

$\mathrm{H}_{3-2}$ The indebtedness level of Cameroonian SME is influenced by their rate of dividend distribution.

$\mathrm{H}_{3-3}$ The higher the growth rate, the stronger the rate of indebtedness.

$\mathrm{H}_{3-4}$ The level of investment opportunities negatively affects the debt of Cameroonian SME.

$\mathrm{H}_{3-5}$ Debt is negatively correlated with the risk of activity.

2.2 Methodology

The sampling frame and the sample, the data and analysis are the landmarks of this methodology.

\subsubsection{Sample}

Our study population only includes SME of the cities of Douala and Yaoundé. Several criteria exist in the literature review to define SME and most authors agree to recognize the primacy of quantitative ones. It is for this reason that we retain here the classification of Chakib (1985) which incorporates that of the Economic and Social Council of Cameroon and is as follows: Small size: 10-49 employees; Medium size: 50-150 employees; Large size: 151-250 employees. This means that the representative units of our sample are SME from the cities of Douala and Yaoundé which have a number of employees between 10 and 250. This criterion appears to be the easiest to identify in documents or to be declared by companies.

The sampling method used is non-random. However, it is difficult to conceive it in our context where there is rarely or not at all an exhaustive list of companies. Files are not always updated when they are founded. Our concern is the representativeness of units concerned hence we proceeded randomly to form a convenient sample.

Out of 102 companies surveyed, only 73 met the criteria for membership of the sample and finally 62 had been subjected to the study. It has the following characteristics:

Table 1. Sample characteristics

\begin{tabular}{llll}
\hline Criteria & Modalities & Number & Percentage \\
\hline Age & 0 to 4 years & 9 & 14.5 \\
& 5 to 11 years & 12 & 19.4 \\
& More than 11 years & 41 & 66.1 \\
\hline City & Douala & 42 & 67.74 \\
& Yaoundé & 20 & 32.26 \\
\hline Number of employees & 10 to 49 employees & 30 & 48.4 \\
& 50 to 150 employees & 25 & 40.3 \\
\hline Turnover & 151 to 250 employees & 7 & 11.3 \\
& 0 to 500 millions & 12 & 19.4 \\
& 500 to 1 billion & 24 & 38.7 \\
\hline Legal form & More than 1 billion & 26 & 41.9 \\
\hline Industry & Public limited company & 30 & 48.4 \\
& Private limited company & 23 & 37.1 \\
& Partnership, sole ownership & 9 & 14.5 \\
\hline
\end{tabular}




\begin{tabular}{llll}
\hline Origin of the property & Family & 25 & 40.3 \\
& Friends without affinity group & 17 & 27.4 \\
& Professional group & 20 & 32.3 \\
\hline Shareholder structure & 1 to 4 partners & 35 & 16 \\
& 5 to 8 partners & 25.8 & 11 \\
& More than 9 partners & 17.7 \\
\hline
\end{tabular}

Note. From the statistics based on our investigations.

\subsubsection{Data and Analysis}

The method of data collection used by the study is the questionnaire. It was administered in a kind of door to door process, facilitated by the grouping of units in industrial, port areas and shopping centers in the city of Douala. By cons, Yaoundé is characterized by a dispersion of representative units in our sample. The key questions are closed with the answers yes or no on the one hand or in the form of ranges on the other.

Assumptions made put together two types of variables, independent and dependent ones. They are diversed in nature and identified from many indicators and varied measures contained in the table below:

Table 2. Indicators and measures of variables

\begin{tabular}{|c|c|c|c|}
\hline Variables & Nature & Indicators & Measurements \\
\hline \multirow{7}{*}{ Profile characteristics } & \multirow{7}{*}{$\begin{array}{l}\text { Independent or } \\
\text { predictive variable }\end{array}$} & Age & Per bracket \\
\hline & & Size & Employee headcount or turnover \\
\hline & & Industry & $\begin{array}{l}\text { Consistent with the classical distribution: } \\
\text { Commerce, Industry, Services }\end{array}$ \\
\hline & & Ownership of capital & Majority shareholding by groups \\
\hline & & Shareholder Structure & Number of partners \\
\hline & & Legal form & commercial forms \\
\hline & & Intensity of control & According to legal forms \\
\hline \multirow{5}{*}{ Operating characteristics } & \multirow{5}{*}{$\begin{array}{l}\text { Independent or } \\
\text { predictive variable }\end{array}$} & Rotation of economic assets & turnover / economic assets \\
\hline & & Time inventory turnover & Stocks*360/turnover \\
\hline & & Term credit providers & Accounts Payable* 360/Total Purchases \\
\hline & & Time of customer credit & Accounts Receivable*360/turnover \\
\hline & & $\begin{array}{l}\text { Importance of the negative } \\
\text { working capital }\end{array}$ & Negative working capital / turnover \\
\hline \multirow{4}{*}{ Performance Characteristics } & \multirow{4}{*}{$\begin{array}{l}\text { Independent or } \\
\text { predictive variable }\end{array}$} & Growth opportunities & Auto financing / Investments \\
\hline & & Rate of Dividend & Paid dividends / Total distributing \\
\hline & & Profitability & Net income / Total Assets \\
\hline & & Rate of growth & Average turnover in 03 years \\
\hline \multirow{3}{*}{ Financial structure } & \multirow{3}{*}{$\begin{array}{l}\text { Dependent or } \\
\text { explanatory variable }\end{array}$} & Level of equities & Equity / Total Liabilities \\
\hline & & Working capital & Permanent capital / assets \\
\hline & & Rate debt & $\begin{array}{l}\text { LMTD (long and medium term debts / } \\
\text { Equity }\end{array}$ \\
\hline
\end{tabular}

Data are of primary nature. Indeed, three tests will be used to verify and validate the assumptions previously issued.

The Chi-squared test $\left(\mathrm{X}^{2}\right)$ is used to analyze the degree of association between variables of nominal kinds. It will firstly provide the relationship between characteristics profile, operation of the company and its financial structure, and secondly on the working capital of the sample firms.

A multivariable analysis will also be conducted using a multiple regression and a discriminant analysis. Indeed, the regression with the tests of Student and Durbin-Watson allow us to refine the analysis by establishing significant correlations between the different explanatory variables described above and the financial structure variables which are the level of equity, the Working Capital Fund and the financial debt.

Discriminant analysis in turn, highlights the most significant variables that distinguish SME experiencing 
deficiency in equity to those experiencing sufficient funds, then the elements of the operation that show performances and discriminate SME depending on their attach to the debt or not.

\section{Characteristics Features and Decisive Factors of the Financial Structure of Cameroonian SME}

The results presented are derived from two types of analysis: a one-dimensional and the other multidimensional

\subsection{A Univariable Analysis of the Characteristics of the Financial Structure of Cameroonian SME}

Univariable analysis search through Chi-square tests, significant relationships between the different variables of profile characteristics, operation and performance history on the one hand and the financial structure of firms on the other one.

\subsubsection{The Relationship between Level of Capital and the Firm's Profile}

Table 3. Results of chi-square Level of capital * profile characteristics

\begin{tabular}{llllll}
\hline Profile Characteristic & Df & Chi-square & Phi & Coefficient of contingency (C) & Signifiance \\
\hline Age & 1 & 4.585 & -0.272 & 0.262 & $0.032^{* *}$ \\
Size (effective number) & 1 & 4.623 & 0.273 & 0.263 & $0.032^{* *}$ \\
Size (Turnover or sales) & 1 & 0.006 & 0.009 & 0.009 & 0.941 \\
Industry & 2 & 4.472 & 0.269 & 0.259 & 0.107 \\
Ownership of capital & 2 & 8.610 & 0.373 & 0.349 & $0.014^{* *}$ \\
Shareholder structure & 1 & 22.808 & 0.611 & 0.522 & $0.000^{* *}$ \\
Control intensity (Legal form) & 2 & 3.862 & 0.249 & 0.241 & 0.147 \\
\hline
\end{tabular}

Note. ** Significant value (SPSS output version 12.0).

The results of khi-square in this first case revealed at 5\% significant value a link between age and average intensity (negative), size (measured by the number of employees), the ownership of capital and the shareholder structure, and the level of capital held by the Cameroonian SME. On the contrary, there is no connection between the size (measured by sales), the intensity of control and the industry (not significant), and the same level of equity. These results are consistent with those obtained in other contexts, namely, that of French listed companies (Redis, 2004) and Moroccan SME (Shakib, 1985) at least for the age, size and industry.

\subsubsection{The Impact of Operating Characteristics on the Financial Structure of SME}

The different crosses made reveal the following relationships:

Table 4. Chi-Square results-capital fund * operating characteristics

\begin{tabular}{|c|c|c|c|c|c|}
\hline Operating Characteristics & Df & Chi-square & Phi & $\begin{array}{l}\text { Contingence } \\
\text { Coefficient }(\mathrm{C})\end{array}$ & Significance \\
\hline Rotation of economic assets & 2 & 12.205 & 0.444 & 0.406 & $0.002 * *$ \\
\hline Inventory Turnover & 2 & 0.97 & 0.127 & 0.126 & 0.607 \\
\hline Term supplier credit & 2 & 5.984 & 0.311 & 0.297 & $0.050^{* *}$ \\
\hline Duration of customer credit & 2 & 1.631 & 0.162 & 0.160 & 0.442 \\
\hline $\begin{array}{l}\text { Importance of NWC (Negative working } \\
\text { capital) }\end{array}$ & 2 & 13.654 & 0.469 & 0.425 & $0.001 * *$ \\
\hline
\end{tabular}

Note. ${ }^{* *}$ Significant value (SPSS output version 12.0 ).

The test results in this second case establish a significant link between the capital and the rotation of economic assets on the one hand, and the importance of the operating working capital on the other hand. However, it does not conclude on a significant relationship between the capital and the rate of inventory turnover on the one hand and duration of customer credit on the other hand. Nevertheless, it has very little significance on the duration of supplier credit. These results do not support arguments with Redis (2004) and those of other authors like Dubois (1985) who used the same indicators in the French context and made the existence of the credit provider a means of financing for companies and the opportunities they have, whether to invest funds obtained by rapidly trading financial assets or to invest in fixed assets. This explains on their part, a negative correlation between capital guarantees and debt rate. 


\subsubsection{Duality of Financial Debt Rate-Performance History of SME}

Table 5. Chi-square results rate of financial debt* performance history

\begin{tabular}{llllll}
\hline Performance Characteristics & Df & Chi-square & Phi & Contingence Coefficient (C) & Significance \\
\hline Investment Opportunities & 1 & 3.119 & -0.224 & 0.219 & 0.077 \\
Rate of Dividend Distribution & 1 & 12.917 & -0.456 & 0.415 & $0.001^{* *}$ \\
Profitability & 1 & 5.175 & -0.289 & 0.278 & $0.023^{* *}$ \\
Rate of growth & 1 & 0.524 & 0.092 & 0.092 & 0.469 \\
Degree of default risk & 1 & 1.281 & 0.144 & 0.144 & 0.258 \\
\hline
\end{tabular}

Note. ${ }^{* *}$ Significant value (SPSS output version 12.0).

It results from this third case of crossover that there exists a significant and highly significant link between profitability, rate of dividend distribution on the one hand and the level of debt on the other one respectively. On the contrary, the test leads to an irrelevant relationship between investment opportunities and debt levels, and a lack of connection with the growth rate and default risk. These predictions are similar to those made by Redis (1984) on French companies, but contradictory to the respective relationships between growth rate, default risk and debt of Cameroonian SME.

At this level of study, the financial structure was analyzed on a one-dimensional angle. The various combination tests made led to a number of significant relationships that confirmed or refuted our hypothesis. But we must recognize that the choice of capital structure is a multidimensional problem which is necessary for further research of the determinants.

\subsection{A Multivariate Analysis of the Determinants of the Financial Structure of Cameroonian SMEs}

It implements a multiple regression analysis on the one hand and on the other one by discrimination.

\subsubsection{A Comprehensive Explanation by Elimination: A Multiple Regression Analysis}

Three models are built for this purpose corresponding to each of the measures of the dependent variable (financial structure), which are: the level of capital, working capital and the rate of financial debt. The method consisted of introducing step-by-step the different explanatory variables and retain only those that improve the percentage of contribution.

The explanatory model of the level of capital covers (Equities):

Table 6. Summary of equities regression and profile characteristics

\begin{tabular}{|c|c|c|c|c|c|c|c|c|c|c|}
\hline Model & $\begin{array}{l}\text { Introduced } \\
\text { variable }\end{array}$ & $\mathrm{R}$ & $\mathrm{R}^{2}$ & $\begin{array}{l}\text { Variation } \\
\text { of } \mathrm{R}^{2}\end{array}$ & $\mathrm{~F}$ & Significance & $\mathrm{t}$ & Significance & $\mathrm{B}$ & Durbin-watson \\
\hline 1 & $\begin{array}{l}\text { Shareholder } \\
\text { Structure }\end{array}$ & 0.595 & 0.354 & 0.354 & 32.903 & 0.000 & 5.736 & 0.000 & 0.531 & \\
\hline \multirow[t]{2}{*}{2} & Shareholder & 0.618 & 0.464 & 0.110 & 25.555 & 0.000 & 6.549 & 0.000 & 0.560 & \\
\hline & $\begin{array}{l}\text { Structure } \\
\text { Size (numbers of } \\
\text { employees) }\end{array}$ & & & & & & 3.480 & 0.001 & 0.297 & $\begin{array}{l}\text { DWcal=2,208 } \\
\text { above } \\
\text { value }=1,77\end{array}$ \\
\hline \multirow[t]{3}{*}{3} & $\begin{array}{l}\text { Shareholder } \\
\text { Structure } \\
\text { Size (number of } \\
\text { employees) }\end{array}$ & 0.719 & 0.517 & 0.052 & 20,660 & 0.000 & 6.668 & 0.000 & 0.547 & \\
\hline & $\begin{array}{l}\text { Ownership of } \\
\text { capital }\end{array}$ & & & & & & -2.509 & 0.015 & -0.121 & \\
\hline & $\begin{array}{l}\text { Theoretical } \\
\text { values }\end{array}$ & & & & 2.17 & & 2.00 & & & \\
\hline
\end{tabular}

Note. SPSS output version 12.0. 
The introduction of explanatory variables of the company's profile improves the percentage of explanation of the variation in the level of equities from 35.4 to $51.7 \%$ in step 3 . There is a strong correlation of about $71.9 \%$ ( $R$ value) between the variables. From this adjustment, it appears that the shareholder structure, the size of the firm measured by number of employees and capital ownership terms contribute respectively $35.4 \%, 11 \%$ and $5.2 \%$ to the variation of the level of capital.

The model is statistically satisfactory, since the theoretical values of $\mathrm{F}$ and $\mathrm{T}$ are lower than those calculated and a significant probability of zero and less than 0.05 in all three steps of the model. The Durbin-Watson test shows that there is no self-correlation between the model's errors (Dwcal $=2.208>1,77$ ). So, the shareholder structure, the size measured in terms of enrolment and ownership of capital constitute profile variables which are susceptible to influence the financial structure of Cameroonian SME. The Chi-square test permit to validate sub-hypothesis $\mathrm{H}_{1-1}$, while the regression analysis confirms those of sub-hypothesis $\mathrm{H}_{1-2}$ and $\mathrm{H}_{1-4}$, but rejects that of sub-hypothesis $\mathrm{H}_{1-3}$.

This multiple regression models at step 3 can be written as follows:

$$
Y=0,293 \times 1-0,121 \times 2+0,546 \times 3+\epsilon
$$

where:

$Y=$ Level of equities, $X 1=$ Shareholder structure, $X 2=$ Size (number of employees), $X 3=$ ownership of capital, $€=$ the error term.

The regression model of the working capital (WC)

Tableau 7. Summary of working capital regression and profile characteristics

\begin{tabular}{lllllllllll}
\hline $\begin{array}{l}\text { Mod } \\
\mathrm{el}\end{array}$ & $\begin{array}{l}\text { Introduced } \\
\text { variable }\end{array}$ & $\mathrm{R}$ & $\mathrm{R}^{2}$ & $\begin{array}{l}\text { Variation } \\
\text { of } \mathrm{R}^{2}\end{array}$ & $\mathrm{~F}$ & Significance & $\mathrm{t}$ & Significance & $\mathrm{B}$ & Durbin-watson \\
\hline 1 & $\begin{array}{l}\text { Speed of } \\
\text { economic assets }\end{array}$ & 0.440 & 0.194 & 0.194 & 14.426 & 0.00 & -3.798 & 0.000 & -0.832 \\
2 & $\begin{array}{l}\text { Speed of } \\
\text { economic assets }\end{array}$ & 0.559 & 0.312 & 0.119 & 13.409 & 0.00 & -3.432 & 0.001 & $-0.712 \begin{array}{l}\text { DWcal=1.996 } \\
\text { above } \\
\text { value }=1.77\end{array}$ \\
& $\begin{array}{l}\text { Importance of } \\
\text { NWC }\end{array}$ \\
Theoretical values & & & & & & -3.191 & 0.002 & -0.614 & \\
\hline
\end{tabular}

Note. SPSS output version 12.0.

Through the same process, we note that the share of the working capital explained by the operating characteristics is quite low (31.2\%), the rate of economic assets contributing to $19.4 \%$ against $119 \%$ for the importance of the negative working capital. Despite a good correlation $(\mathrm{R}=0.559>0.5)$, an analysis of variance shows that the adjustment is not of good quality because the working capital is only very little explained by the said variables $(\mathrm{R} 2=0.312<0.5)$. The Fisher-Snedecor test however shows that the model is globally significant and that of T-student allows us to see that the variables are also significant. There is no error and self-correlation between their terms. In this way, the importance of the working capital of Cameroonian SME depends on the speed of economic access and the importance of negative working capital. The Chi-square test validate sub-hypothesis $\mathrm{H}_{2-3}$, while the regression analysis confirms those of sub-hypothesis $\mathrm{H}_{2-1}$ and $\mathrm{H}_{2-5}$ but rejects those of sub-hypothesis $\mathrm{H}_{2-2}$ and $\mathrm{H}_{2-4}$.

This implies the regression models below at step 2

$$
Y=-0,712 \times 1-0,614 X 2+\epsilon
$$

Where: $\mathrm{Y}=$ working capital, $\mathrm{X} 1=$ Speed of economic assets, $\mathrm{X} 2=$ Importance of $\mathrm{NWC}, €=$ the error term The regression model of financial debt. 
Tableau 8. Summary of financial debts and growth characteristics

\begin{tabular}{|c|c|c|c|c|c|c|c|c|c|c|}
\hline Model & $\begin{array}{l}\text { Introduced } \\
\text { variable }\end{array}$ & $\mathrm{R}$ & $\mathrm{R}^{2}$ & $\begin{array}{l}\text { Variation } \\
\text { of } \mathrm{R}^{2}\end{array}$ & $\mathrm{~F}$ & Significance & $\mathrm{t}$ & Significance & $\mathrm{B}$ & Durbin-watson \\
\hline 1 & $\begin{array}{l}\text { Rate of dividend } \\
\text { distribution }\end{array}$ & 0.456 & 0.208 & 0.208 & 15.790 & 0.00 & -3.974 & 0.000 & -0.482 & $\begin{array}{l}\text { DWcal }=2.061 \\
\text { above } \quad \text { value }=\end{array}$ \\
\hline \multirow[t]{3}{*}{2} & $\begin{array}{l}\text { Rate of dividend } \\
\text { distribution }\end{array}$ & & & & & & -3.815 & 0.000 & 0.53 & 1.77 \\
\hline & & 0.516 & 0.265 & 0.057 & 10.627 & 0.00 & & & & \\
\hline & Profitability & & & & & & -2.129 & 0.037 & -0.123 & \\
\hline
\end{tabular}

Note. SPSS output version 12.0.

The regression results highlight the fact that the history of performance explains very weakly the variations of the rate of financial debt (26.5\% of explained variance) of the sampled firms. Although the model is statistically very significant, the $\mathrm{T}$ Student's test led to reject several variables and only the rate of dividend distribution (20.8\%) and profitability (5.7\%) are significant. These results have already been obtained for the French case by Redis (2004) and Morocco by Chakib (1985). It emerges from this that the level of financial indebtedness of Cameroonian SME is influenced at the same time by the rate of distribution of dividends and by its profitability. The results of the Chi-square test and those from the regression analysis confirm the validation of the sub-hypothesis $\mathrm{H}_{3-1}$ and $\mathrm{H}_{3-2}$, while those of sub-hypothesis $\mathrm{H}_{3-3} \mathrm{H}_{3-4}$ and $\mathrm{H}_{3-1}$ are rejected.

So, the equation model can be written as follow:

$$
Y=-0,453 \times 1-0,123 \times 2+\epsilon
$$

Where: $\mathrm{Y}=$ Financial debt, $\mathrm{X} 1=$ Rate of dividend distribution, $\mathrm{X} 2=$ Profitability, $€=$ the error term.

\subsubsection{A Classification Test Based on the Most Significant Variables: A Discriminant Analysis}

From a partition, we distinguish three cases according to our assumptions. First, we look at the profile elements that distinguish SME experiencing a deficiency in capital cover from those experiencing sufficient funds, secondly, the operating elements that make the operation more aware or not of the minimum financial equilibrium and at last in order to detect a history of performance that discriminates SME according to the great importance they attach to financial debt or not. The discriminant analysis conducted through a step by step statistics produced the following results:

Discrimination in terms of adequacy or not of capital cover:

It appears from Wilks' Lambda test and from the summary of discriminant functions (Table 9) that only variables such as the share holder structure, and in the least measure the size and the ownership capital, are subject to discrimination between enterprises in situation of insufficiency and sufficiency of funds.

Table 9. Summary of canonical discriminant functions of profile variables

\begin{tabular}{llll}
\hline Variables explicatives & Matrix of structure & $\begin{array}{l}\text { Fisher discriminant function } \\
\text { Insufficiency of Equities }\end{array}$ & Sufficiency of Equities \\
\hline Shareholder Structure & 0,716 & $-8.907 \mathrm{E}-02$ & 5.413 \\
Size (employee numbers) & 0.275 & 1.009 & 3.956 \\
Ownership of capital & -0.273 & 1.848 & 0.634 \\
Turnover & 0.191 & & \\
Legal form & 0.114 & & \\
Activity domain & -0.068 & & \\
Age & 0.045 & -2.037 & -3.931 \\
Constant & 1 & & \\
\hline
\end{tabular}

Note. SPSS output version 12.0 .

According to this summary table, only the shareholder structure, the size and ownership of capital can introduce discrimination between sufficiency and insufficiency of equities. The coefficient of the Fisher discriminant function indicates that firms in situation of insufficiency of equities are more influenced by their size and the ownership of their capital, whereas those in situation of sufficiency are highly influenced by the shareholder 
structure and their size.

The final ranking table indicates that $90.3 \%$ of the original observations are correctly classified, which reflect the quality of the selected criteria (see appendix).

Discrimination in terms of compliance or not of-financial equilibrium. The table presents the results of the Fisher discriminant function:

Table 10. Summary of canonical discriminant functions variables financial equilibrium

\begin{tabular}{|c|c|c|c|c|}
\hline \multirow[t]{2}{*}{ Explanatory variables } & \multirow[t]{2}{*}{$\begin{array}{l}\text { Matrix } \\
\text { structure }\end{array}$} & \multicolumn{3}{|l|}{ Fisher discriminant Function } \\
\hline & & $\begin{array}{l}\text { Non-respect of the financial } \\
\text { equilibrium }\end{array}$ & $\begin{array}{l}\text { Respect of the } \\
\text { equilibrium }\end{array}$ & financial \\
\hline $\begin{array}{l}\text { Importance of NWC (Negative working } \\
\text { capital) }\end{array}$ & 0.741 & 2.768 & 2.744 & \\
\hline Duration of customer credit & 0.316 & & & \\
\hline Speed of rotation of economic assets & 0.680 & 4.613 & 3.667 & \\
\hline Duration of customer credit & -0.036 & & & \\
\hline Inventory turnover & -0.032 & & & \\
\hline Constant & & -3.811 & -3.160 & \\
\hline
\end{tabular}

It is clear from this table that the importance of NWC (Negative working capital) and the speed of rotation of economic assets are the two most significant variables that explain the differences between business groups. The discriminant function shows that a third group has been formed, but did not have any signification because the Wilks Lambda value is too high. The classification results show that in adopting these conclusions we notice that $74.2 \%$ of the original observations have been highly ranked in their respective groups as indicated by the results (in appendix).

Discrimination with respect to privilege for financial debt:

In the latter case of discrimination, the rate of dividend distribution and the rate of return of the company explain most significantly differences in financial debt ratio of SMEs in our sample as indicated by the results of following table.

Table 11. Summary of canonical discriminant functions of the importance of debt

\begin{tabular}{llll}
\hline Explanatory variables & Matrix structure & $\begin{array}{l}\text { Fisher discriminante Function } \\
\text { Little importance }\end{array}$ & Great importance \\
\hline Distribution rate & 0.865 & 2.7701 & 0.256 \\
Profitability & 0.503 & 1.078 & 3.395 \\
Growth rate & -0.237 & & \\
Investment opportunities & 0.69 & & \\
Degree of risk & 0.003 & -1.822 & -0.764 \\
Constant & & & \\
\hline
\end{tabular}

In this case, the rate of dividend distributed and profitability are reputed to explain significantly differences of financial debt rate of SME of our sample.

The coefficients of Fisher discrimination function highlight the fact that SME which attach little importance to the financial debt are guided largely by the rate of dividend distribution, then their profitability, while those that attach great importance to the financial debt are almost always by their rate of return. As in the previous case, the reclassification is performed at $74.2 \%$.

\section{Conclusion and Discussion}

Overall, the univariable analysis allowed us to initially establish that the age, the nature of ownership, shareholding structure, size of the workforce are the characteristic profiles of Cameroonian SME that may influence the level of capital, the intensity of control and the activity sector having no impact on the latter. These results confirm those of Ziane (2004) who suggests that the life span representative of informational capital of 
the company on the market of debt pushes it to have resort to debt than on self- financing of Dubois (1985) and Charreaux (1991) who attribute the privilege of self-financing in order to guarantee the independence of SME which are predominantly linked to the family. Also, the financial position of a firm can be explained better by the structure of its accounts belonging to a specific sector. On the contrary, the more shareholding is diffused, the more firms use debts to solve the problems of conflict. This can be demonstrated by the almost absence of control costs in the Cameroonian environment. Indeed, SME do not lend or lend little to the opening of the capital and are mostly one-person companies (SARL and PLCs) thus distorting the data on intensity control and definition of legislative bodies although OHADA took care to specify the different levels of control.

However, contrary to the agency's theory, there is a positive relationship between the level of owned capital and ownership structure, because the more ownership is diffuse, the more Cameroonian SME use owned funds. Everything suggests that these entities are far from suffering control costs due to a large number of shareholders, which is contrary to Jensen and Meckling proposals.

Therefore, working capital depends mainly on the speed of economic assets and on the importance of negative working capital. These results have also been obtained already by Chakib (1985) in Moroccan SME, by Malécot (1982) in the process of failure of SME. However, the importance of credit supplier in the decision of the resorting or not to owned capital is logical, given the importance that many of them give to credit between companies.

Moreover, the rate of dividend distribution, and the rates of return are the antecedent variables of performance that negatively affect on the financial indebtedness of these companies and enable their behavior to be qualified as pecking order (Myers \& Maljuf, 1984). These results reinforce the positions of the pecking order theory (the more a company pays, the more it borrows) and precludes to considerations of the theory of signal that expresses that the rate of return and distribution are signals sent to lenders that increase the borrowing capacity of their clients.

These first analyses allow us to draw conclusions on the verification of assumptions made above. In a second step, the integration of multivariable analysis deepened relations already highlighted and corrected errors in the predictions.

It appears from the Fisher and Wilks' Lambda validation tests that the ownership structure, the size of the company measured in quantity, capital ownership, the speed of economic assets, the importance of negative working capital, the rates of profitability and dividend distribution are the most significant determinants of financial structure of Cameroonian SME. The first three profile characteristics allow for a clear classification between Cameroonian SME according to their level of capital. Thus, those companies in a situation of insufficient funds will be influenced by their size and capital ownership, while those living in sufficiency undergo an extensive influence of their ownership structure and size. The speed of economic assets, the importance of working capital may also explain the differences between SME that meet the minimum or non-financial balance, as well as the rate of dividend distribution and profitability remain the two variables that explain the differences in financial debt rate between Cameroonian SME.

Table 12. Summary of the results of validation of hypotheses

\begin{tabular}{llll}
\hline Key assumptions & Sub- hypotheses & Verification \\
\hline & The age or period of life of the SME influences the level its own funds & Verified \\
& The size of the Cameroonian SMEs positively influences the level of capital cover & Verified \\
& Size measured in terms of quantity & Rejected \\
$\begin{array}{l}\text { The level of equity in the } \\
\text { Cameroonian SME depends on its } \\
\text { profile characteristics }\end{array}$ & $\begin{array}{l}\text { Size measured in terms of turnover } \\
\text { The proportion of capital cover held by the company varies with its activity sector }\end{array}$ & $\begin{array}{l}\text { Rejected } \\
\text { Verified }\end{array}$ \\
& $\begin{array}{l}\text { The importance of capital cover of a SME varies depending on the nature of the } \\
\text { property on the one hand, the number of shareholders and the control intensity on the } \\
\text { other hand }\end{array}$ & Rejected \\
\hline $\begin{array}{l}\text { The debt rate of the Cameroonian } \\
\text { SME is influenced by } \quad \text { its } \\
\text { performance history }\end{array}$ & $\begin{array}{l}\text { The indebtedness level of Cameroonian SMEs is negatively influenced by their rate of } \\
\text { profitability on the one hand dividend distribution on the other }\end{array}$ & Verified \\
& The higher the growth rate, the stronger the rate of indebtness & Verified \\
& The level of investment opportunities negatively affects the debt of Cameroonian & Rejected \\
\hline
\end{tabular}


Debt is negatively correlated with the risk of activity

The level of working capital of the company varies with the speed of rotation economic assets and / or speed of rotation of stocks

The importance of working capital of Cameroonian SME depends on its operating characteristics working capital of Cameroonian SMEs depends on the duration of the supplier credit and customer credit

The more need for working capital by a company, the greater its working capital is increased
Rejected

verified

Rejected

Verified

Rejected

Verified

\section{References}

Allouche, J., \& Amann, B. (1995). Le retour triomphant du capitalisme familial. In De Jacques Cœur à Renault (Eds.), Gestionnaire et Organisations. Presses de l'Université des Sciences sociales de Toulouse.

Bédué, A. (1997). Les déterminants de la structure financières des entreprises françaises. Thèses de Doctorat, Université de Paris Nanterre.

Biais, B., Hillion, P., \& Malécot, J. F. (1995). La structure financière des entreprises : une investigation sur données françaises. Economie et Prévision, 120(4), 15-28.

Bourdieu, J., \& Colin-Sédillot, B. (1993). Structure du capital et coûts d'information: le cas des entreprises françaises à la fin des années 80. Economie et Statistique, 87-100. http://dx.doi.org/10.3406/estat.1993.5812

Carpentier, C., \& Suret, J. M. (1999). Stratégies de financement des entreprises françaises: Une analyse empirique. Serie Scientifique (CIRANO), 99-109.

Carpentier, C., \& Suret, J. M. (2000). Pratique et théorie du financement: le cas de la France. Finance, 21(1), 9-34.

Chakib, E. F. (1985). Contribution à l'étude de l'insuffisance des fonds propres dans les PME industrielles: Le cas des PMEI marocaines. Thèse de Doctorat.

Charreaux, G. (1991). Structures de propriété, relation d'agence et performance financière. Revue Economique, 3 , 521-552.

Colot, O. (2005). La transmission des PME-Résultats de l'enquête. Qualiera, Université de Mons- Hainaut, 69.

Colot, O., \& Croquet, M. (2007). Le caractère familial d'une PME influence-t-il le niveau d'endettement financier. La Revue du Financier, 164, 72-90.

Cordier, J., \& Sicsic, P. (1999). Endettement des entreprises: Peut-on parler d'un rationnement de crédit? Revue D'Economie Financière, 163-175.

Croquet, M., Heldenbergh, A., \& Pozniak, L. (2013). Profils de financement des grandes entreprises: Le cas de la Belgique. La Revue des Sciences de Gestion, Direction et Gestion, 111-129.

De Jong, A., \& Van, D. R. (1998). Determinants of leverage and agency problems. Tilburg University, Center for Economic Research.

Desbrières, Ph., \& Dumontier, P. (1989). Dettes ou fonds propres: Comment choisir? Revue Française De Gestion, 5-14.

Dubois, M. (1985). Les déterminants de la structure financière: Le cas des grandes entreprises françaises. Finance, 6, 42-70,

Fazzari, S. M., Hubbard, R. G., \& Peterson, B. C. (1988). Financing constraints and corporate investment. Brooking papers in Economic Activity, 1, 141-206

Fontaine P., \& Njiokou, C. (1996). Les déterminants de la structure financière: une comparaison international. Banque Et Marchés, 24, 121-134,

Fotsa, L. L. (2014). Mésofinance: Une analyse des déterminants de l'accès au crédit des petites entreprises dans u contexte de mutation de l'industrie de la microfinance. La Revue du Financier, 35, 85-97.

Gaud, P., \& Jani, E. (2002). Déterminants et dynamique de la structure du capital des entreprises suisses: Une étude empirique. Cahiers De Recherche, 12.

Harris, M., \& Raviv, A. (1988). Corporate control contest and capital structure. Journal of financial Economics, 20, 55-86. http://dx.doi.org/10.1016/0304-405X(88)90040-2 
Harris, M., \& Raviv, A. (1991). The theory of capital structure. Journal of Finance, 46(1), 297-355.

Hirigoyen, G. (1982). Le comportement financier des moyennes entreprises industrielles familiales. Banques, 417, 588-593.

Jensen, M. C., \& Meckling, W. H. (1976). The Theory of the firm: managerial behaviour, agency costs and

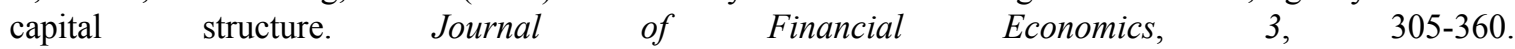
http://dx.doi.org/10.1016/0304-405X(76)90026-X

Johnson, S. A. (1997). An empirical analysis of the determinants of corporate debt ownership structure", European Economic Review, 44, 281-304.

Kremp, E., \& Stôss, E. (1999). L'endettement des entreprises industrielles françaises et allemandes: Des évolutions distinctes malgré des déterminants proches. Economie et Statistique, 341-342.

Lefilleur, J. (2009). Financer lesPME dans un contexte de forte asymétrie d'information. In le financement des PME en Afrique subsaharienne, Secteur privé et développement. La revue de Proparco, (1), 14-16.

Leland, H. E., \& Pyle, D. H. (1977). Informational asymetries, financial structure and financial intermediation. Journal of Finance, 32(2), 45-63.

Maî Django, T., \& Tsapi, V. (2013). Determinants factors of dividend distribution in Cameroon companies. African Journal of Business Management, 7(7), 579-590.

Malécot, J. F. (1982). Les défaillances : un essai d'explication. Gestion, 37.

Meyers, S. C. (1977). Determinants of corporate borrowings. Journal of Financial Economics, 5, 147-175. http://dx.doi.org/10.1016/0304-405X(77)90015-0

Meyers, S. C., \& Majluf, N. S. (1984). Corporate financing and investment decisions when firms have information that investors do not have. Journal of Financial Economics, 13.

Miller, M. H. (1977). Debt and taxes. Journal of Finance, 32(2), 261-275.

Mulkay, B., \& Sassenou, M. (1995). La hiérarchie des financements des investissements des PME. Revue Economique, 46(2), 345-363.

Ndoume, E. (2003). Les fondements et développement de la structure financière des entreprises : une synthèse théorique et empirique. Revue des Sciences de Gestion, Direction et Gestion, 99-114.

Nekhili, M. (1994). Choix entre la dette bancaire et la dette obligatoire par les firmes françaises. Thèse de Doctorat, Université de Bourgogne.

Poincelot, E. (1999). Le rôle de l'endettement dans le contrôle du comportement managérial: le cas des firmes dégageant du free cash-flow. Finance, contrôle et Stratégie, 2(1), 75-89.

Rainelli-Lemontagner, H. (1998). Structure du capital et secteur d'activité: étude sur des données internationals. In Marchés financiers et gouvernement de l'entreprise: Actes des XIVè journées nationales des IAE.

Rajan, R., \& Zingales, L. (1995). What do we know about capital structure? Some evidence from international data. Journal of Finance, 50, 1421-1460.

Redis, J. (2002). Contribution à la connaissance du financement des entreprises en France. Evolution du comportement de financement des sociétés françaises cotées et pouvoir explicatif des modèles théoriques (1960-1996). Thèse pour Doctorat ès Sciences de Gestion, Université Montesquieu Bordeaux IV.

Redis, J. (2004). Les déterminants internes de la structure financière des sociétés françaises cotées. Revue des Sciences de Gestion, Direction et Gestion, 105-122. http://dx.doi.org/10.1051/larsg:2004042

Remmars, L. Stonehill, A., Wright, R., \& Beekhuisen, T. (1974). Industry and size as debt ratio determinants in manufacturing internationally. Financial Management, 24-32.

Romieu, N., \& Sassenou, N. (1996). Quels liens établir entre la structure d'actionnariat de la firme et ses performances économiques et financières? Flash, Caisse des Dépôts et Consignations, 96-101.

Ross, S. (1977). The determination of financial structure: the incentive signaling approach. Bell Journal of Economics, 8, 23-40.

Scott, J. H. (1976). A theory of optimal capital structure. Bell Journal of Economics, 33-54. http://dx.doi.org/10.2307/3003189

Shuetrim, G., Lowe, P., \& Morling, S. (1993). The determinants of corporate leverage: a panel data analysis. 
Reserve Bank of Australia, 1-52.

Stiglitz, J., \& Weis, A. (1981). Credit rationing in markets with imperfect information. American Economic Review, 71, 393-410.

Stulz, R. (1988). Managerial control of voting rights: financing policies and the market for corporate control. Journal of financial Economics, 20, 25-54.

Tioumagneng, A. (2012). Banques et comportement d'endettement des enterprises. Revue Recherches En Sciences De Gestion, 89, 81-99.

Toy, N., Stonehill, A., Remmers, L., Wright, R., \& Beekhuisen, T. (1974). A comparative international study of growth, profitability and risk as determinants of corporate debt ratio in manufacturing sectors. Journal of Financial and Quantitative Analysis, 875-886. http://dx.doi.org/10.2307/2329684

Trahan, E. A., \& Gitman, L. J. (1995). Bridging the theory-practice gap in corporate finance: a survey of chief financial officers. The Quartely Review of Economics and Finance, 35(1), 73-87. http://dx.doi.org/10.1016/1062-9769(95)90063-2

Williamson, O. (1988). Corporate finance and corporate governance. Journal of Finance, 43, 567-591. http://dx.doi.org/10.1111/j.1540-6261.1988.tb04592.x

Yassine, L., (2013). Determinants of bank financing for small and medium enterprise. Gestion, 29-47.

Ziane, Y. (2004). La structure d'endettement des PME françaises: Une étude sur données de panel. Revue Internationale PME, 17(1), 123-137.

\section{Appendix}

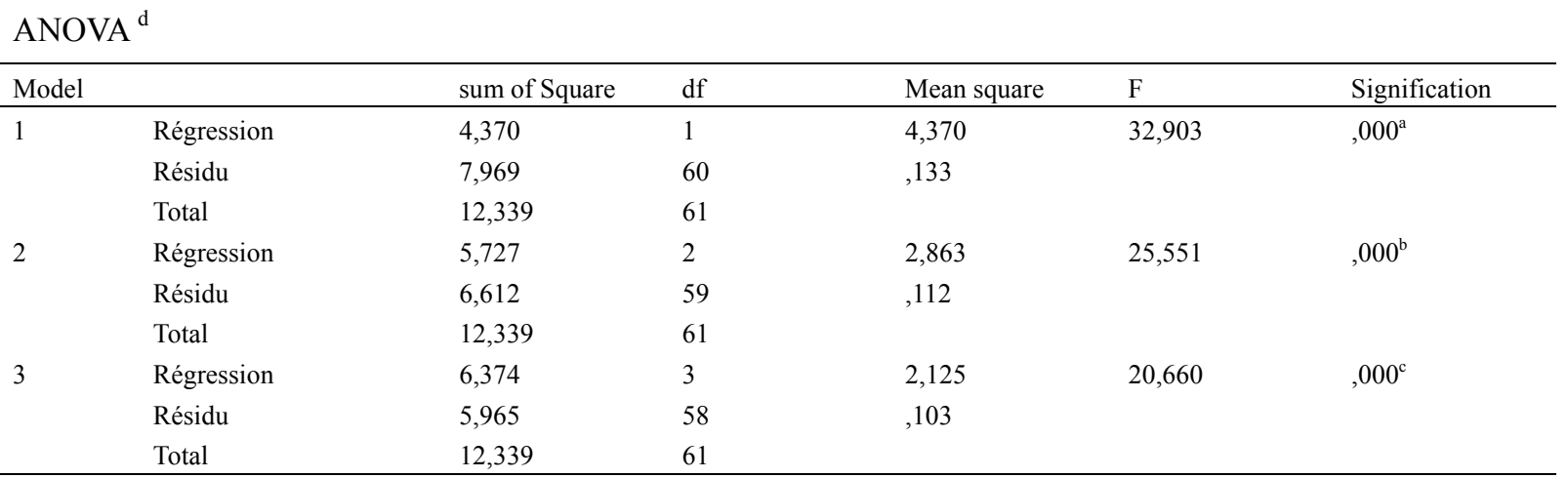

Note ${ }^{a}$ Predicted values: (constants), shareholder structure; ${ }^{\mathrm{b}}$ Predicted values: (constants), shareholder structure, Size (number of employees); ${ }^{\mathrm{c}}$ Predicted values:(constants), shareholder structure, Size (number of employees), capital ownership; ${ }^{\mathrm{d}}$ Independent variable: importance of Equities (Equities/Total debt).

\begin{tabular}{|c|c|c|c|c|c|c|}
\hline \multicolumn{2}{|c|}{ Model } & \multirow{2}{*}{$\begin{array}{l}\text { sum of Square } \\
9,129\end{array}$} & \multirow{2}{*}{$\frac{\mathrm{df}}{1}$} & \multirow{2}{*}{$\begin{array}{l}\text { Mean square } \\
9,129\end{array}$} & \multirow{2}{*}{$\begin{array}{l}\mathrm{F} \\
14,426\end{array}$} & \multirow{2}{*}{$\begin{array}{l}\text { Signification } \\
, 000^{\mathrm{a}}\end{array}$} \\
\hline 1 & Régression & & & & & \\
\hline & Résidu & 37,968 & 60 & ,633 & & \\
\hline & Total & 47,097 & 61 & & & \\
\hline \multirow[t]{3}{*}{2} & Régression & 14,718 & 2 & 7,359 & 13,409 &, $000^{\mathrm{b}}$ \\
\hline & Résidu & 32,379 & 59 &, 549 & & \\
\hline & Total & 47,097 & 61 & & & \\
\hline
\end{tabular}

Note. ${ }^{\mathrm{a}}$ Predicted values: (constants), speed of economics assets; ${ }^{\mathrm{b}}$ Predicted values: (constants), speed of economics assets, importance of negative working capital; ${ }^{\mathrm{c}}$ Independent variable: Working capital. 
ANOVA $^{\mathrm{c}}$

\begin{tabular}{|c|c|c|c|c|c|c|}
\hline \multicolumn{2}{|c|}{ Model } & \multirow{2}{*}{$\begin{array}{l}\text { sum of Square } \\
3,065\end{array}$} & \multirow{2}{*}{$\frac{\mathrm{df}}{1}$} & \multirow{2}{*}{$\begin{array}{l}\text { Mean square } \\
3,065\end{array}$} & \multirow{2}{*}{$\begin{array}{l}\mathrm{F} \\
15,790\end{array}$} & \multirow{2}{*}{$\begin{array}{l}\text { Signification } \\
, 000 \mathrm{a}\end{array}$} \\
\hline 1 & Régression & & & & & \\
\hline & Résidu & 11,645 & 60 & ,194 & & \\
\hline & Total & 14,710 & 61 & & & \\
\hline \multirow[t]{3}{*}{2} & Régression & 3,896 & 2 & 1,948 & 10,627 &, $000^{\mathrm{b}}$ \\
\hline & Résidu & 10,814 & 59 &, 183 & & \\
\hline & Total & 14,710 & 61 & & & \\
\hline
\end{tabular}

Note. ${ }^{\text {a }}$ Predicted values: (constants), Rate of dividend distribution.

${ }^{\mathrm{b}}$ Predicted values: (constants), Rate of dividend distribution, profitability.

${ }^{\mathrm{c}}$ Independent variable: Financial debt rate.

Table 1. Results of reclassification ${ }^{\mathrm{a}}$

IMPORTANCE OF EQUTIES

\begin{tabular}{llll}
\hline & \multicolumn{2}{l}{ Classe(s) d'affectation prévue (s) } \\
\cline { 2 - 4 } \cline { 3 - 4 } Importance of equities cover (Equities/Total debt) & Insufficiency of capital cover & Sufficiency of capital cover \\
\hline Original Quantity Insufficiency Of capital cover & 17 & 0 & Total \\
Sufficiency of Cover capital & 6 & 39 & 17 \\
\hline \%Insufficiency Of capital cover & 100.0 & 0 & 45 \\
Sufficiency of Cover capital & 13.3 & 86.7 & 100.0 \\
\hline
\end{tabular}

Note. $90.3 \%$ of original observations classified correctly.

Table 2. Results of reclassification ${ }^{\mathrm{a}}$

FINANCIAL DEBT

\begin{tabular}{llll}
\hline Financial debt rate & \multicolumn{2}{l}{ Class(es) of scheduled assignment (s) } \\
\cline { 2 - 4 } & $\begin{array}{l}\text { Low rate of financial } \\
\text { debt }\end{array}$ & $\begin{array}{l}\text { Medium to high rate of financial } \\
\text { debts }\end{array}$ & 38 \\
\hline Original Quantity Low rate of financial debt & 27 & 11 & 24 \\
Medium to High rate Of financial debt & 5 & 28.9 & 190.0 \\
\hline \% Low rate of financial Debt & 71.1 & 79.2 & 100.0 \\
\hline Medium to high rate Of financial debt & 20.8 & & 38.2 \\
\hline
\end{tabular}

Note. 74.2 original observations classified correctly.

Table 3. Results of reclassification ${ }^{\mathrm{a}}$ Respect of financial equilibrium

\begin{tabular}{|c|c|c|c|c|c|}
\hline \multirow[t]{2}{*}{ Working capital } & \multicolumn{3}{|l|}{ Class(es) of scheduled assignment (s) } & \multirow[b]{2}{*}{2} & \multirow[b]{2}{*}{ Total } \\
\hline & $\begin{array}{l}\text { Non respect of Financial } \\
\text { equilibrium }\end{array}$ & $\begin{array}{l}\text { Respect of } \\
\text { equilibrium }\end{array}$ & Financial & & \\
\hline $\begin{array}{l}\text { Original Quantity non respect of the minimum financial } \\
\text { equilibrium }\end{array}$ & 35 & 5 & & 2 & 42 \\
\hline Respect of the minimum & 2 & 1 & & 1 & 4 \\
\hline Financial equilibrium 2 & 6 & 0 & & 10 & 16 \\
\hline$\%$ non-respect of the minimum financial equilibrium & 83.5 & 11.9 & & 4.8 & 100.0 \\
\hline Respect of the minimum & 50.0 & 25.0 & & 25.0 & 100.0 \\
\hline Financial equilibrium 2 & 37.5 & 0.0 & & 62.5 & 100.0 \\
\hline
\end{tabular}

Note. a. 74.2 original observations classified correctly. 


\section{Copyrights}

Copyright for this article is retained by the author(s), with first publication rights granted to the journal.

This is an open-access article distributed under the terms and conditions of the Creative Commons Attribution license (http://creativecommons.org/licenses/by/3.0/). 